\title{
'Thursdays in Black campaign' and the blackening of the widow's body: A hermeneutic of suspicion to blackening of the body to resist gender-based violence
}

\begin{tabular}{|c|c|}
\hline \multicolumn{2}{|c|}{$\begin{array}{l}\text { Author: } \\
\text { Sinenhlanhla S. Chisale }{ }^{1}\end{array}$} \\
\hline \multicolumn{2}{|c|}{$\begin{array}{l}\text { Affiliation: } \\
{ }^{1} \text { Department of Practical } \\
\text { Theology and Missiological } \\
\text { Studies, Faculty of Theology } \\
\text { and Religion, University of } \\
\text { Pretoria, Pretoria, } \\
\text { South Africa }\end{array}$} \\
\hline \multicolumn{2}{|c|}{$\begin{array}{l}\text { Research Project Registration: } \\
\text { Project Leader: Y. Dreyer } \\
\text { Project Number: } 2546930\end{array}$} \\
\hline \multicolumn{2}{|c|}{$\begin{array}{l}\text { Project Description: } \\
\text { Dr Chisale is participating in } \\
\text { the research project, 'Gender } \\
\text { Studies and Practical } \\
\text { Theology Theory Formation', } \\
\text { directed by Prof. Dr Yolanda } \\
\text { Dreyer, Department of } \\
\text { Practical Theology, Faculty of } \\
\text { Theology and Religion, } \\
\text { University of Pretoria. }\end{array}$} \\
\hline \multicolumn{2}{|c|}{$\begin{array}{l}\text { Corresponding author: } \\
\text { Sinenhlanhla S. Chisale, } \\
\text { sinengwenya@gmail.com }\end{array}$} \\
\hline \multicolumn{2}{|c|}{$\begin{array}{l}\text { Dates: } \\
\text { Received: } 10 \text { Apr. } 2021 \\
\text { Accepted: } 14 \text { July } 2021 \\
\text { Published: } 07 \text { Sept. } 2021\end{array}$} \\
\hline \multicolumn{2}{|c|}{$\begin{array}{l}\text { How to cite this article: } \\
\text { Chisale, S.S., 2021, } \\
\text { "“Thursdays in Black } \\
\text { campaign" and the } \\
\text { blackening of the widow's } \\
\text { body: A hermeneutic of } \\
\text { suspicion to blackening of the } \\
\text { body to resist gender-based } \\
\text { violence', HTS Teologiese } \\
\text { Studies/Theological Studies } \\
77(2), \text { a6731. https://doi. } \\
\text { org/10.4102/hts.v77i2.6731 }\end{array}$} \\
\hline \multicolumn{2}{|l|}{ Read online: } \\
\hline 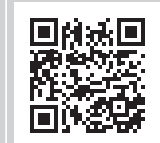 & $\begin{array}{l}\text { Scan this QR } \\
\text { code with your } \\
\text { smart phone or } \\
\text { mobile device } \\
\text { to read online. }\end{array}$ \\
\hline
\end{tabular}

Black is used as a colour of darkness, death, evil, bad luck and mourning. Generally, most cultures around the world use black as a colour of mourning, and widows from the African culture, in particular, are expected to wear all-black attire for a year to mourn their husbands. Although this colour is associated with death and mourning, contemporary women's movements have reintroduced black as a colour of resistance and resilience. This article applies African feminist critical hermeneutics of suspicion to the Thursdays in Black (TIB) campaign and blackening of the widow's body and attire. The aim is to explore how this campaign is contrary to the blackening of the widow's body and attire in their cause and how the campaign's wearing of black is emotionally divorced from the struggles of widows who experience distress, sadness and shame by wearing the black attire.

Contribution: The article applies an African feminist hermeneutics of suspicion to the colour black used by the TIB campaign for solidarity with victims of sexual and gender-based violence (SGBV). It questions the relevance of this campaign to a widow who puts on a black attire for mourning.

Keywords: African feminist hermeneutics of suspicion; black dress; black colour; sexual and gender-based violence; widow's body and attire; Thursdays in Black campaign.

\section{Introduction}

Colour is very important in African culture and religion and is not taken for granted. Black is often used as a colour of darkness, death, evil, bad luck and mourning. Generally, a black dress or doek is for a woman grieving her husband or child in most African cultures, particularly Southern Africa. Among traditional Africans in Zimbabwe, this dress or doek is prepared out of cheap, deep black material after the burial of the departed husband and is for the widow to wear, throughout the grieving process. Immediate family members are given small pieces of the same black cloth to pin on their clothes as a symbol of mourning and solidarity with the mourning widow. When a woman's child dies, the woman does not wear an all-black dress or doek but rather she only puts a black doek on for a year or sometimes 6 months, as a symbol of mourning. During the time of mourning, the woman mourning her husband is not supposed to be seen in public spaces, such as shops, parties or seen celebrating.

The black dress or doek embodies the darkness and difficult life, filled with social isolation and stigmas that a grieving woman goes through. This differs from culture to culture. In this article, I will use examples from the Zimbabwean Ndebele culture. Death among Africans has both cultural and religious aspects to it, and it is intertwined and organised into a set of rituals that introduce the initial response to death. These responses differ between women and men; a woman is expected to put on a black garment and doek of widowhood that embodies sorrow and mourning her husband, and a man is expected to pin on a small piece of the black cloth on his arm to mourn his wife. The widowhood garment, which is commonly made from a cheap black material and at times Royal Blue cotton material, embodies a theology that is rooted in the relationship of the body and mourning. According to Manala (2015:2), the wearing of the black dress is symbolic as these are also referred to as clothes of darkness, which blacken the widow's body. The blackening of the widow's body is compared to an infectious sickness, hence the isolation from normal life activities.

Note: Special Collection: Women Theologies, sub-edited by Sinenhlanhla S. Chisale (Midlands State University) and Tanya van Wyk (University of Pretoria).

Copyright: @ 2021. The Authors. Licensee: AOSIS. This work is licensed under the Creative Commons Attribution License. 
This blackening of the widow's body through a black attire is parallel to the ecumenical campaign that is called Thursdays in Black (TIB), which is against sexual and gender-based violence (SGBV). The campaign that was started by the World Council of Churches (WCC) in the 1980s is a form of peaceful protest against the rape and violence that takes place in countries at war or that have conflict (WCC 2020a:np). According to the WCC website, TIB was revived on 31 October 2013 during the WCC 10th Assembly in Busan, in the Republic of Korea, where participants were encouraged to wear black. The WCC explained that in the TIB campaign, black is used as a colour of resistance and resilience and not necessarily of mourning. The campaign was inspired by several movements, which protested against violence and rape such as:

- The Mothers of the Disappeared in Buenos Aires, Argentina, who on Thursdays protested at the Plaza de Mayo, against the disappearance of their children during the violent dictatorship in the 1970s.

- The Women in Black in Israel and Palestine, who protested against war, militarism and violence in the 1980s.

- Women in Rwanda and Bosnia who protested against the use of rape as a weapon of war in the 1990s.

- The Black Sash movement in South Africa protesting against apartheid and its use of violence against black people in the 1950s (WCC 2020b:n.p.).

The use of black as a colour for resistance, resilience and protest against the oppression and violence perpetuated on the female body has emerged as a contemporary culture. Normally, black is known as a colour of death and mourning and it has been diversely used for that purpose by different cultures, particularly its symbolic meaning that is denoted by the widow's dress. As a result, in some cultures, a black dress is identified as the widows' attire. The aim of this article is to highlight if or not women and men who wear black on Thursdays embody true solidarity with widows who wear black for mourning and are victims of SGBV. The article applies African feminist critical hermeneutics of suspicion to the blackening of the body in the TIB campaign and the widow's body during mourning. In this article, the blackening of the body by wearing the black attire is used to communicate lived theologies by different women from different contexts. Thus, the article, firstly describes the methodology and theoretical framework. Secondly, the article explores how colour black in the TIB campaign is contrary to the black used in the widow's attire in their cause and purpose. Thirdly, an African feminist critical hermeneutics of suspicion is applied to the blackening of the body in TIB campaign and widows. Fourthly, the article discusses the interplay of the TIB campaign with the lived experiences of widowhood and lastly are the concluding remarks.

\section{Methodological considerations and African feminist critical hermeneutics of suspicion}

This article was conceived as a result of noticing the struggles of widows who have gone through the process of blackening of their bodies with a black attire to mourn their departed husbands on one hand, while on the other hand, it was motivated by questions asked by postgraduate students, some of whom are widows in a gender and religion class on the relevance of TIB campaign towards ending SGBV. As a result, in this article, I seek to apply African feminist critical hermeneutics of suspicion to the blackening of the body in the TIB campaign parallel to the blackening of the widow's bodies during mourning. This study is positioned in the feminist epistemology that allows individuals to raise their subjective suspicions in research. This does not necessarily call for large samples of data to confirm, but feminist research applies what Harding (1993:50) calls the feminist standpoint that legitimises subjective knowledge and gives researchers space for complexity and contradictions. According to Harding (1987:9), objectivity in feminist research is achieved by examining the researcher's position within the research conducted, and this becomes visible in the assumptions and biases that emerge because of the researcher's gender, race, class, ethnicity, assumptions and beliefs. Thus, in feminist research, objectivity is inconsequential as researchers examine 'the social world from a grounded position in their own subjective oppression' (Weiler 1988:122). In this article, African feminist critical hermeneutics of suspicion is applied to the blackening of the body from subjective oppression as the author of the article.

\section{African feminist critical hermeneutics of suspicion}

African feminist critical hermeneutics of suspicion applied in this article is drawn from African feminist cultural hermeneutics theory that was conceptualised by Kanyoro (2001a) and Oduyoye (2001). It emphasises an analysis of cultural variables influencing the African woman's lived experiences. African feminist critical hermeneutics of suspicion is realised when interpretation is balanced. Dreyer (2011:2) says that in hermeneutics of suspicion, one should firstly understand what lies behind the text (history and origin), secondly understanding what is in the text (connections and understanding the structure and finding one's place in the system) and thirdly the placing of oneself in front of the text (experience we bring to it). In African feminist critical hermeneutics of suspicion, women are suspicious of dehumanising cultural and religious teachings (Phiri \& Nadar 2006a:6). According to Kamaara and Wangila (2009:131), African feminist critical hermeneutics of suspicion exposes the social reality of a given group. This theory allows us as women and the marginalised, to question our oppression by challenging the public transcripts used to define our bodies. It is a useful tool for reflecting on women's politics of the body, as we embody suffering, marginalisation, resistance and solidarity. This theory is applied to the blackening of the body in the TIB campaign and the widow's body and attire. It exposes the androcentric and power connotations of the text in question. In this article, the symbolic meaning of the black colour in the TIB campaign and widow's dress is explored and analysed. 


\section{Colour in context theory}

Social psychologists have developed theories to study the link between colour and human psychological functioning. This theory of colour by Goethe dates back to 1810 when he linked colour categories to emotional responding (Elliot 2015:1). Drawing from social learning and biology, Elliot and Maier (2012) coined the colour in context theory. The assumption of this theory is that colour triggers relations that contain psychologically relevant messages that influence the psychological functioning of people and may substitute motivational and behavioural processes. Colour is contextspecific and has a symbolic value for different people; thus, colour can result in opposite motivational processes (Elliot \& Maier 2012:67). According to social psychologists, colour informs the diversity of perception depending on the physical context in which it is viewed (Adelson 1994; Elliot \& Maier 2012:109). The colour red has been extensively researched and tested, as a colour of romance, sex and passion (Meier et al. 2012:1), and has association with intellectual and sports performance (Meier et al. 2015:11, 16), and the colour black has been researched as a colour of death and evil (Johnson et al. 2014:8-9). However, colour perceptions vary according to race, culture, religion, age and class.

\section{Putting black colour into context: Black as a colour of death and darkness}

Traditionally and religiously, black is used as a colour of death, to be worn during mourning, meaning symbolically that the grieving family is covered by darkness or a dark cloud. In African traditional religion, the black colour is often associated with bad luck or calamity. Thus, frequently perceptions connect the black colour to bad omens, evil, death and darkness. Although some cultures use different colours for mourning other than black, black has been used as a normal colour of death and darkness since time immemorial. The perception of using the black colour for darkness has been challenged for causing racism towards black people from the African continent. According to Jarosz (1992:106), associating the African continent with darkness, as was and is done by Euro-American discourses, is the result of defining Africa 'within a web of dualities such as light/ dark, found/lost, life/death, civilized/savage, known/ mysterious, tame/wild, and so on'. The colour black and darkness are often feared because of the negative and frightening stereotypes that are attached to them. Grieve's study (1991:1322) on the perceptions about colour highlights that the strong association of the colour black with death is discouraging educated black women in African contexts from wearing pure black clothing in their everyday life, unless the colour is matched or blended with white or any other bright colour. The colour black embodies evil, witchcraft and dark forces in African folktales and symbols and this discourages Africans from using the black colour in their decorations or make-up, as this will raise suspicions of witchcraft or evil.
The association of black with darkness and death has also discouraged manufacturers from packaging their products in black. Participants in Kumar's (2017:6) study on the psychology of colour and the influences it has on consumer buying behaviour associated black with evil and death. In a sporting experiment, researchers perceived players who wore colour black as evil and more aggressive than those who wore other colours (Johnson et al. 2014:8-9). Negative perceptions of the colour black contribute to the stigmatisation of the blackened widow's body and attire.

The Christian perception of black is that it is a symbol of darkness or impurity. In Christian contexts, some churches use black as a liturgical colour for vestments on Good Friday and burials. This perception still associates the colour black as a colour of death and evil (Elliot \& Maier 2012:64; Kumar 2017:6). Some Christians use black colour to commemorate the passion, or suffering, and death of Jesus Christ on the Cross on Good Friday. Colour black in this context is used to embody the suffering and pains that Christ experienced on the journey to the Cross. Nevertheless, not all of the Christian churches use colour black on Good Friday, some use diverse colours including purple, white and red. Biblically and hermeneutically, Good Friday is a positive occasion for the Christian community because the event happens for the redemption of the world. In the Bible, black is a colour that embodies sin, disease, sorrow, death, famine and judgement (see Job 6:15-16; 30:30; Lm 4:6-8; 5: 7-10; Mi 3:6; Rv 6:5-6; Jud 1:12-13; Jr 13:15-17). As a result, the colour black is figuratively both negative and positive; however, the church focused on the evil of this colour more than the purity by ascribing it to the devil, causing ambiguity on its significance with respect to church liturgy.

In African traditional contexts, the blackening of the widow's body and attire is symbolic of her weakness, emptiness, unavailability, misery, suffering, lacking and disability. Mamphela Ramphele (1996:99) describes the lived realities of the widow when she says, a widow's body is the 'embodiment of loss and pain occasioned by the sting of death, and her body is turned into a focus of attention, as both subject and object of mourning rituals'. Ramphele (1996) further says that the body of a widow is:

$[M]$ arked in different communities by some or all of the following practices: shaving her head, smearing a mixture of herbs and ground charcoal on her body, wearing black clothes made from an inexpensive material and covering her face with a black veil and her shoulders with a black shawl. (p. 100)

Blackness of the body and the rituals performed on her symbolise both death and darkness. This leads to the stigmatisation of the widow's body; the mourning black dress makes her visible and vulnerable to social isolation, shame, exclusion of her body and subject of pity. It is believed that she embodies misery, bad omens (umnyama) and evil. As a result, she is not allowed to be in public spaces. Her situation is treated as infectious. If she goes to public spaces, she is often excluded from other people; when using public 
transport, passengers prefer to stand in the bus, rather than sit next to her. In churches and public spaces, widows in mourning attire sit in the back seats because of perceptions that they may expose other congregants in church or other travellers in public transport to bad omens or bad luck (Kotzé, Lishje \& Rajuili-Masilo 2012:755). Focus and locus are on her sexual and physical body, rather than the grief she goes through. Her sexual body is subordinated to negative theological interpretations that destroy her inner person by prioritising the symbolic and political hermeneutics and beliefs of the blackening of her body and attire.

\section{Black dress as a colour of resistance}

Although black is commonly associated with evil, bad omen, darkness, death and mourning, this colour is also associated with power and strength. During the Victorian era, widows used the mourning black dress in fashionable ways. In explaining the fashion of the black dress of widowhood, Mitchell (2013) quotes Sarah Ellis who explains that the widow's black dress during the Victorian era was used as both a:

[L]ady-like fashionable style of mourning, that, under the memory of the dead, it has become an object of ambition excellence; and equally an object of dread, and source of humiliation to be compelled to wear it in an inferior style. (p. 600)

Seemingly widows in the Victorian era used the black mourning dress in ways that were twofold: to embody loss and misery on one hand, and liberation and power on the other. This use of the mourning black dress by widows led to the evolution of the little black dress. The little black dress, which became visible between the 19th and 20th centuries, is perceived by some women as symbolic in boosting selfconfidence, feelings of being more feminine, more sexually experienced and more desirable (Mitchell 2013:598).

According to Feisner (2004:17), the positive characteristics of the black dress became visible in the 19th century, when black was reinvented as a colour of sophistication, power, luxury, sexuality and high fashion. Fashion designers like Christian Dior, Donna Karan and other famous designers made the little black dress popular, by declaring that it was an essential for every woman's wardrobe (Mendes 1999:9). A black dress ceased to be just a mourning dress but was reinvented to be classic expensive fashion. Black dresses made of expensive material became visible in the clothing market and were worn by powerful women such as Princess Diana (Provo 2013:44). Provo (2013:44) quotes the Design Museum that outlined the fifty dresses that changed the world and one of those dresses included Princess Diana's little black dress which journalists called the 'revenge dress' which she wore on a Vanity Fair dinner in London on the eve her husband Prince Charles acknowledged of his affair in 1991 (Provo 2013:44). Reports say that Princess Diana who wore all black appeared sexier, sensational and more confident than before. She was portrayed as victorious, a vision of strength and independence wearing that dress (Provo 2013:44). One may argue that seemingly she knew that her husband was going to confess about the affair, and as a result, she wore all black in mourning the end of her marriage on one hand, and embodying selfconfidence, victory and liberation on the other.

The black dress communicates and embodies diverse symbolic meanings. Some perceive the black dress as flirtatious, sexy and seductive. MacDonnell Smith quoted in Mitchell (2013:614) says that the black mourning dress 'had its sexy side ... unlike that other group of unavailable women, unmarried girls, widows weren't virgins. They were forbidden fruit, but ripe'. According to Mitchell (2013:602), they looked sexy and beautiful in their mourning black dresses and embodied two qualities which included 'maintaining her dignity and status as the angelic, devoted wife at the same time that her clothed body can be read as sexually experienced, desiring, and desirable'. Seemingly, these widows used their mourning black garments to resist the traditional purpose of the mourning black garment, which embodied misery, suffering and distress. The TIB campaign uses black as a colour of resistance against the violence perpetuated against women and children because of patriarchy, war, colonialism, capitalism and all other power politics. According to WCC's (2020a:np) website on TIB, black colour raises awareness about incest, child pornography, domestic violence, sexual abuse perpetrated against individuals simply because of their gender and perceived weakness or inferiority. The wearing of black as a colour of resistance, protest and resilience is not regulated nor imposed on people's bodies by the TIB campaign. In the context of TIB, black embodies solidarity and hope to end all forms of violence. In explaining a pastoral response to violence that has become an epidemic in South Africa, Ackermann (2001) applies healing as a theological praxis to:

$[T]$ hose who are suffering, marginalised and oppressed as well as those who have privilege and power to be in solidarity, provided they too understand its genesis in the hope for a restored creation and are willing to hear the pain of the suffering of 'the other' and to act response. (p. 107 [Author's added emphasis.])

In her discussion of SGBV in South Africa, she tackles the question of agency and choice as extremely significant in the search for appropriate theological and pastoral response to violence (Ackermann 2001:105-106). This seems to be the emphasis of the TIB campaign, where participants have a choice in how they use black to embody resistance, resilience and hope.

\section{An African feminist critical hermeneutics of suspicion and the blackening of the body}

The TIB campaign is visible in ecumenical organisations and institutions of higher learning, particularly religious and theological institutes. It is not clear who is genuinely targeted by this campaign, because it is not visible to those who are at grassroots. Is this campaign only for elite and 
educated feminist theologians? Why is it only visible in ecumenical organisations and theological institutes? Is it an elite and educated feminist theology movement? Why does it use colour black? How is black colour empowering to a widow who has gone through violence during the process of wearing a black attire for mourning and experienced SGBV ${ }^{1}$ ? As Maluleke (2021:299, 301) raises his hermeneutic of suspicion on African Public Theology, so I raise my suspicions of TIB campaign. Maluleke (2021) rightly argues that he has seen and witnessed different theologies that come:

$[A]$ dorned in colourful robes and dazzling jewels: each singing the praises of its own name, each promising to surpass the one before it, each promising to be better connected to the true sources of theology, each doing its best to hide its imperial intentions. (p. 298)

Like Maluleke, I see some imperial intentions in the TIB campaign. It is conceptualised and controlled by those who choose to ignore that blackening of the body has undesirable cultural and religious connotations to a widow.

In an era of decolonisation, where everything is being decolonised including knowledge and knowing, one cannot help but question intent of some of these campaigns promising to liberate women and girls. In describing the decolonisation of theology, Higgs (2007:80) says that 'to decolonise theology is to engage in a process of contesting, critiquing, and creatively reworking the imperial, patriarchal, and colonial institutions and categories of Christianity'. To decolonise is able to point at the hidden powers and agendas that are used to perpetuate colonialism. According to Ndlovu-Gatsheni (2012:1), coloniality is the 'invisible power structure that sustains colonial relations of exploitation and domination long after the end of direct colonialism'. African women theologians have been engaged in the decolonisation of theology particularly feminist theology for decades now. Mercy Oduyoye's launch of the Circle of Concerned African Women Theologians (hereafter 'the Circle') in August 1988 was the beginning of rigorous decolonisation of women theologies.

Having been raised in an African Christian and traditional context, I have had to work hard in order to negotiate a balance between the two. Although the two traditions are parallel in many ways, the Circle theories particularly African feminist cultural hermeneutics by Kanyoro (2001a) and Oduyoye (2001) and African womanist (bosadi) hermeneutics by Masenya (1995) gave me hope and consolation. I can engage in what Phiri and Nadar (2006b:7) call 'narrative activism', where as an insider and from a subjective approach, I critique the hegemony of western knowledge while reflecting on 'oppressive practices in African religio-culture' without guilt. Culturally, the black attire or dress is for mourning, however the western fashion designers and elite women redefined a black dress as a symbol of power and

1.Some widows are forced to go through a sexual cleansing ritual by having unprotected sex with the brother or male relative of the departed husband, unprotected sex with the brother or male relative of the departed husband,
sometimes the ritual is performed by having unprotected sex with a village cleanser sometimes the ritual is performed by having unprotected sex strength (Provo 2013:44). This makes me suspicious if the black attire in the TIB campaign is genuinely inspired by the historical movements which protested against violence and rape, or it is inspired by the rhetoric of the fashion designers who identify it as a symbol of power and strength? It is not clear how the black attire in the TIB campaign is an embodiment of resistance, resilience and solidarity to cultures and religions that perceive this colour as a symbol of mourning, darkness, death, evil and bad luck. To such, the blackening of the body in the TIB campaign otherwise highlights a power aspect. Although, in general, women experience domination from men, the TIB campaign seems to be a tool of control and domination by elite and educated women over women from the grassroots in order to carry on the radical feminists' agenda to transform women from conservative communities, particularly in Africa. The obvious suspicion being that the campaign is directed by elite and educated women who have privilege and power to redefine their status quo through how they dress their bodies, which unfortunately a widow does not have.

The black attire is used in two opposing contexts. In the context of a widow, the symbolic meaning of the black dress comprises isolation and behaviour control by patriarchal culture. While in a context of TIB, symbolically the black dress comprises power and autonomy. The TIB campaign radically shifts the traditional meaning of the black dress. It is unfortunately not empowering the widows whose emotions and behaviour are connected to the darkness of her body. Generally, some of those who wear black on Thursdays' behaviour and emotions are contrary to the message they try to embody through the black dress. In the TIB campaign, the colour and the emotions are divorced, and contrary, those wearing black on Thursdays are seen posing for photographs in high spirits, checking and commenting on each other's dresses and often in celebratory moods. The TIB campaign is reduced to a fashion show rather than a solidarity movement. A victim of SGBV often goes through emotional trauma and torture, and a campaign in solidarity should be sensitive to such. In a context of mourning and solidarity, black colour is a colour of sadness and isolation. Although I participate in the TIB campaign, I do so with reservations remembering women who have experienced abuse and violence in the process of the blackening of their bodies for mourning and women and girls who experience SGBV because of their physical weaknesses.

Maluleke (2021:301) argues that some emerging theologies never state their imperial ambitions and homogenising designs upfront. They emerge as a liberation movement or theology, yet behind the mask of liberation, the intention is to dominate and control the dominant spaces. Patriarchy does not come in a form of a male figure dominating and oppressing a female figure, it comes in diverse ways that include class, gender, race, religion and ethnicity. As a result, for me, the contrary hermeneutics in blackening the body for mourning and blackening the body for solidarity, resistance, resilience and protest exposes the top-down approach and power struggle that exists among women, meaning that in 
the struggle to end oppression and violence against women, women from the grassroots experience domination by elite and educated women. This domination by women towards other women is parallel to Kanyoro's (2001a:107) analysis, as she explains that women are not only victims but there are incidents of women's dominance against women at the grassroots. This is also highlighted by Allen (1999:122) who asserts that women do not only experience male domination, but domination has become complex because some women dominate others because of race, class, ethnicity, age or sexual orientation. This domination of women by other women is because of the power dynamics, which are caused by different social contexts. These power dynamics affect women at the bottom of the ladder, who in the presence of the elite and the educated feel compelled to be silent. In this struggle, women have become their own worst enemies and contribute to the delay of gender justice, regardless of some women's efforts to win this struggle.

\section{Interplay of the Thursdays in Black campaign to the lived experiences of widowhood}

Although elite and educated women develop and implement solidarity and resistant strategies to end violence against women and children in good faith, different social contexts make this difficult. Thus, all groups of women including the educated, elite and those at the grassroots should be allowed to critically apply hermeneutics of suspicion in dialogue with each other. What may seem liberative to one group may in reality be oppressive to the other. Thus, radical feminist views of resistance are not always relevant and applicable to all women, particularly conservative women, and their sociocultural contexts.

The body is a flexible tool in cases of oppression and liberation. On the one hand, the body is used to oppress the self by conforming to oppressive societal norms, and on the other hand, it can be used to liberate the self by resisting oppressive norms. Although class is salient in the way blackness of the body embodies oppression and liberation, I need to be fair to the TIB campaign in connection to widowhood's blackening of the body. In contexts of widowhood, the body is docile, controlled or disciplined according to cultural norms (Foucault 1995:136). The widow is expected to conform to cultural norms of widowhood, emotionally and physically. Thus, the widow's black attire is associated with despair, stigma, evil, social exclusion, sexual control and weakness. In this case, the body is often put under surveillance to be monitored for compliance. While in the TIB campaign, the blackness of the body or black attire is linked to the feminist dictum that says the 'personal is political'. It is personal in that all women are vulnerable and may have experienced different forms of violence in their lifetime. It is political in that the violence perpetuated on women's bodies is a public and political issue that should be addressed publicly, to raise public and political responsive awareness. In the personal is political, the body is used to communicate distress and solidarity. The emotions, conduct and physical appearance of the body are connected, and this raises my suspicion of the TIB campaign as a solidarity movement, because emotions and conduct are disconnected to the purpose of colour. It may be unfair of me to expect TIB campaign to be in solidarity with the widow's plights because their objectives do not explicitly target the widow; however, as feminist or womanist movement, I believe that this campaign is inclusive of all women, including the plights of a widow. Thus, one expects the TIB campaign as a solidarity movement of victims of SGBV to empathise with widows, meaning that their conduct and emotions should be aligned to empathic solidarity.

\section{Empathic solidarity}

My argument is that although TIB is a solidarity campaign, the movement lacks empathy with those who have painfully experienced SGBV in the process of the blackening of their bodies, particularly widows. It also lacks empathic solidarity with a woman or a girl who has been raped and forced to be in silent isolation and traumatised. Empathy is defined by Clinebell (1984:77) in his book, Basic types of pastoral care and counselling as the ability to 'feel with others' in order to understand what they experience in the inner self. Clinebell (1984:77) argues that to be able to respond positively and effectively to what a person is going through, we should avoid trying to develop solutions for the challenges of others, but rather we should focus our response to being with them caringly in their inner world. Lartey (2003:92) describes it as entering into another person's inner feelings and ways of understanding the world. Empathic solidarity with widows and victims of SGBV occurs when those in solidarity are able to enter into their feelings without judging or critiquing them. In empathic solidarity, the conduct and emotions should match the dress code. It is like a soldier who goes to war, where emotions and the conduct match the attire and mass destructive weapons she or he carries. The TIB campaign as a solidarity movement should avoid further hurting the victims of SGBV and limiting the widow's plight through their divorced emotions and behaviour. In empathic solidarity, those in solidarity should be prepared to lose their inner peace and power for the sake of the other. Lartey (2003) says:

[E]mpathy involves an accurate awareness of another person's feelings, the ability to 'stay with' these feelings no matter how painful or inexplicable and being able to express or enable their expression. (p. 92)

In empathic solidarity, the powerful becomes vulnerable; thus, Chisale (2018:8) says, it takes place where there is mutual dialogue, and differences are not in opposing ends, but matching because of the vulnerability to comparable oppressions, thus those in solidarity challenge violations of human dignity as insiders and outsiders. Empathic solidarity leads to reflective introspection, and in this case, the one in solidarity, for example TIB campaign, should be able to navigate and tap into the uncomfortable psychologies and theologies that exist in the widow and victims of SGBV's inner and external bodies for responsive healing. 
With empathic solidarity, there is no hierarchy or power struggle; the two are on par and in a silent reflective dialogue as they listen to what they feel and experience internally. The TIB campaign's use of blackening of the body for solidarity, as it is, is not relevant to the widow's suffering in the process of blackening of the body and to the pains of victims of SGBV. The black dress itself is symbolic of pain rather than a fashion show. Anyone wearing black for solidarity should remember that and be in empathic solidarity, meaning that they should strip themselves of the power they have in order to journey with the affected persons towards their healing. The TIB campaign should align emotions with the blackening of the body and connect cause and purpose. The TIB campaign, being the movement controlled by the elite and educated women, some of whom are informed by Euro-American ways of life, enforcing missionary theologies that ignore culture in the quest for the liberation of African women is problematic in itself. Oduyoye and Kanyoro have critiqued theologies that ignore the pains of African women by ignoring that Christian faith in Africa cannot but interact with African culture (Kanyoro 2001b:103; Oduyoye 1979:112). They raise our consciousness, in that, we should not overlook that African women exist in their culture and faith; thus, they developed a cultural hermeneutics approach to enable African women to interpret their lived realities and to recognise that culture is dynamic and evolving and not something given (Oduyoye 1996:13). In the process of interpreting their lived realities, African women are able to apply hermeneutics of suspicion that go hand in hand with hermeneutics of commitment, as they take up the responsibility to challenge, change and transform oppressive customs so that all will enjoy the fullness of life (Oduyoye 2001:11-12). Although the TIB campaign advocates for a world without violence, I believe that it should be more sensitive to the lived realities of the widows, who go through the dehumanising rituals and stigma because of the blackening of the body and their attire. The TIB campaign could achieve this through the expression of empathic solidarity.

\section{Conclusion}

The aim of this article was to highlight if women and men who wear black on Thursdays in the TIB campaign embody true solidarity with widows who wear black for mourning. The article applied African feminist critical hermeneutics of suspicion to the TIB campaign and the blackening of the widow's body. Findings confirm that the blackness of the attire exposes the lived realities of these women, and as a result, the two contexts of TIB and widowhood attire are connected on one hand and disconnected on the other. They are connected in that lived theologies are communicated through their bodies and disconnected in that class is salient leading to power and control of the latter in this struggle. As a result, in applying African feminist critical hermeneutics of suspicion, the use of black to embody solidarity has a weakness of overlooking the widows' struggle because it lacks empathy.

\section{Acknowledgements}

The author acknowledges the contributions made by all undergraduate and postgraduate students she has taught and engaged with on 'African feminism and politics of the body' through class discussions and assignments.

\section{Competing interests}

The author declares that she has no financial or personal relationships that may have inappropriately influenced her in writing this article.

\section{Author's contributions}

S.S.C. is the sole author of this article.

\section{Ethical considerations}

This article followed all ethical standards for research without direct contact with human or animal subjects.

\section{Funding information}

This research received no specific grant from any funding agency in the public, commercial or not-for-profit sectors.

\section{Data availability}

Data sharing is not applicable to this article as no new data were created or analysed in this study.

\section{Disclaimer}

The views and opinions expressed in this article are those of the author and do not necessarily reflect the official policy or position of any affiliated agency of the author.

\section{References}

Ackermann, D., 2001, 'From violence to healing: The struggle for our common humanity', in I.T. Douglas \& K. Pui-lan (eds.), Beyond colonial Anglicanism; The Anglican communion in the twenty-first century, pp. 101-120, Church Publishing Incorporated, New York, NY.

Adelson, E.H., 1994, 'Perceptual organization and the perception of brightness', Science 262(5142), 2042-2044. https://doi.org/10.1126/science.8266102

Allen, A, 1999, The power of feminist theory: Domination, resistance, solidarity, Westview Press, Boulder.

Chisale, S.S., 2018, "Disabled motherhood in an African community": Towards an African women theology of disability', In die Skriflig 52(1), a2375. https://doi. org/10.4102/ids.v52i1.2375

Clinebell, H., 1984, Basic types of pastoral care and counselling: Resources for the ministry of healing and growth, Abingdon Press, Nashville, TN.

Dreyer, Y., 2011, 'Women's spirituality and feminist theology: A hermeneutic of suspicion applied to "patriarchal marriage"', HTS Teologiese Studies/Theological Studies 67(3), Art. \#1104, 5 pages. https://doi.org/10.4102/hts.v67i3.1104

Elliot, A.J., 2015, 'Color and psychological functioning: A review of theoretical and empirical work', Frontiers in Psychology 6, 368. https://doi.org/10.3389/ fpsyg.2015.00368

Elliot, A.J. \& Maier, M.A., 2012, 'Color-in-context theory', Advances in Experimental Social Psychology 45, 63-125. https://doi.org/10.1016/B978-0-12-394286-9.00002-0

Feisner, E.A., 2004, Color studies, 3rd edn., Fairchild Publications, Inc, New York, NY.

Foucault, M., 1995, Discipline and punish: The birth of prison, Vintage Books, New York NY.

Grieve, K.W., 1991, 'Traditional beliefs and colour perception', Perceptual and Motor Skills 72(3), 1319-1323. https://doi.org/10.2466/pms.1991.72.3c.1319

Harding, S., 1987, 'Introduction: Is there a feminist method?', in S. Harding (ed.), Feminism and methodology: Social science issues, pp. 1-14, Indiana University Press, Bloomington, IN. 
Harding, S. 1993, 'Rethinking standpoint epistemology: What is "strong objectivity"?', in L. Alcott \& E. Potter (eds.), Feminist epistemologies, pp. 49-82, Routledge, New York, NY.

Higgs, E.T., 2017, 'Postcolonial feminist theologies', in S.M. Hawthorne (ed.), Gender God, pp. 79-93, Macmillan Reference USA, Farmington Hills, MI.

Jarosz, L., 1992, 'Constructing the Dark Continent: Metaphor as geographic representation of Africa', Geografiska Annaler. Series B, Human Geography 74(2), 105-115. https://doi.org/10.1080/04353684.1992.11879634

Johnson, K., Sharron, J., Lennon, S.J. \& Rudd, N., 2014, 'Dress, body and self: Research in the social psychology of dress', Fashion and Textiles 1(20), 3-24. https://doi. org/10.1186/s40691-014-0020-7

Kamaara, E. \& Wangila, M.N., 2009, 'Contextual theology and gender reconstructions in Kenya', Theologies and Cultures VI(2), 110-133.

Kanyoro, M.R., 2001a, Introducing feminist cultural hermeneutics: An African perspective, The Pilgrim Press, Cleveland, $\mathrm{OH}$.

Kanyoro, M.R., 2001b, 'Cultural hermeneutics: An African contribution', in M.W. Dube (ed.), Other ways of reading: African women and the Bible, pp. 101-113, Society of Biblical Literature, Atlanta, GA.

Kotzé, E., Lishje, L. \& Rajuili-Masilo, N., 2012, “"Women ... mourn and men carry on” African women storying mourning practices - A South African example', Death Studies 36(8), 742-766. https://doi.org/10.1080/07481187.2011.604463

Kumar, S., 2017, 'The psychology of colour influences consumers 'buying behaviourA diagnostic study', Ushus-Journal of Business Management 16(4), 1-3. https:// doi.org/10.12725/ujbm.41.1

Lartey, E., 2003, In living color: An intercultural approach to pastoral care and counselling, 2nd edn., Jessica Kingsley, London.

Maluleke, T., 2021, 'Why I am not a public theologian', World Council of Churches 73(2), 297-315. https://doi.org/10.1111/erev.12602

Manala, M.J., 2015, 'African traditional widowhood rites and their benefits and/or detrimental effects on widows in a context of African Christianity', HTS Teologiese Studies/Theological Studies 71(3), Art. \#2913, 9 pages. https://doi.org/10.4102/ hts.v71i3.2913

Masenya, M., 1995, 'African womanist hermeneutics: A suppressed voice from South Africa speaks', Journal of Feminist Studies in Religion 11(1), 149-155.

Mendes, V., 1999, Black in fashion, V\&A, London.

Meier, B.P., D’Agostino, P.R., Elliot, A.J., Maier, M.A. \& Wilkowski, B.M., 2012, 'Color in context: Psychological context moderates the influence of red on approach-and avoidance-motivated behavior', PLoS One 7(7), 1-5, e40333. https://doi. org/10.1371/journal.pone.0040333

Meier, M.A., Hill, R.A., Elliot, A.J. \& Barton, R.A., 2015, 'Color in achievement contexts in humans', in A.J. Elliot, M.D. Fairchild \& A. Franklin (eds.), Handbook of color psychology, Cambridge handbooks in psychology, pp. 568-584, Cambridge University Press, Cambridge.
Mitchell, R.N., 2013, 'Death becomes her: On the progressive potential of Victorian mourning', Victorian Literature and Culture 41(4), 595-620. https://doi. org/10.1017/S1060150313000132

Ndlovu-Gatsheni, S.J., 2012, Coloniality of power in development studies and the impact of global imperial designs on Africa, inaugural lecture delivered at the University of South Africa, Senate Hall, Pretoria, 16th October.

Oduyoye, M.A., 1979, 'The value of African religious beliefs and practices for Christian theology', in K. Appiah-Kubi \& S. Torres (eds.), African theology en route: Papers from the Pan-African conference of Third World theologians, December 17-23, 1977, Accra, Ghana, pp. 109-116, Orbis Books, Maryknoll, NY.

Oduyoye, M.A., 1996, 'The Impact of women's theology on the development of dialogue in EATWOT', Voices from the Third World 19(1), 11-33.

Oduyoye, M.A., 2001, Introducing African women's theology, Sheffield Academic Press, Sheffield.

Perry, B., Oluoch, L., Agot, K., Taylor, J., Onyango, J., Ouma, L. et al., 2014, 'Widow cleansing and inheritance among the Luo in Kenya: The need for additional women-centred HIV prevention options', Journal of the International AIDS Society 17(1), 19010. https://doi.org/10.7448/IAS.17.1.19010

Phiri, I.A. \& Nadar, S., 2006a, 'What's in a name? Forging a theoretical framework for African women's theologies', Journal of Constructive Theology 12(2), 5-24.

Phiri, I.A. \& Nadar, S., 2006b, 'Introduction: Treading softly but firmly', in I.A. Phiri \& S. Nadar (eds.), African women, religion, and health. Essays in honour of Mercy Amba Ewudsiwa Oduyoye, pp. 1-16, Cluster Publications, Pietermaritzburg.

Provo, L.M., 2013, 'The little black dress and the essence of femininity', Masters of Design in Design, University of Cincinnati.

Ramphele, M., 1996, 'Political widowhood in South Africa: The embodiment of ambiguity', Daedalus 125(1), 99-117.

Vera Cruz, G., Mateus, A. \& Dlamini, P.S., 2018, 'HIV prevention: Mapping Mozambican people's views on the acceptability of the widow's sexual cleansing ritual called pita-kufa', BMC International Health and Human Rights 18(37), 1-9. https://doi. org/10.1186/s12914-018-0177-z

Weiler, K., 1988, Women teaching for change: Gender, class and power, Bergin \& Garvey, New York, NY.

World Council of Churches (WCC), 2020a, Thursdays in black, viewed 14 January 2020, from https://archived.oikoumene.org/en/get-involved/ thursdays-in-black.

World Council of Churches (WCC), 2020b, Thursdays in Black: Zero tolerance for violence against women, viewed 14 January 2020, from https://www.oikoumene. org/en/press-centre/news/thursdays-in-black-zero-tolerance-for-violenceagainst-women. 